Jurnal IImu Komunikasi UHO : Jurnal Penelitian Kajian IImu Komunikasi dan Informasi.

Volume 6, No. 4, Oktober 2021, hlm 548-569

\title{
STUDI ETNOGRAFI KOMUNIKASI : AKTIVITAS MELAUT SEBAGAI SUMBER KEHIDUPAN MASYARAKAT SUKU BAJO SAMPELA
}

\author{
Wa Ode Sitti Nurhaliza \\ Dosen Fakultas Ilmu Komunikasi, Universitas Bhayangkara Jakarta Raya \\ Kampus II Jl. Raya Perjuangan Bekasi Utara, Kota Bekasi, Jawa Barat, Indonesia \\ wa.ode@dsn.ubharajaya.ac.id
}

\begin{abstract}
Abstrak
Penelitian ini fokus pada aktifitas komunikasi dalam kegiatan melaut yang dilakukan oleh masyakat suku bajo sampela. Aktifitas komunikasi yang yang melibatkan bahasa dan budaya dalam serangkaian aktivitas melaut masyakat suku bajo Sampela. Peneliti akan menggambarkan aktivitas masyarakat suku bajo sampela serta simbol verbal dan nonverbal yang dipakai. Penelitian ini bertujuan untuk untuk menjelaskan aktifitas komunikasi dalam masyarakat suku Bajo Sampela yang menyangkut bahasa, simbol nonverbal yang dipakai dalam budaya melaut. Dengan menggunakan metode etnografi komunikasi, peneliti fokus pada cara-cara komunikasi yang dilakukan masyarakat suku bajo Sampela dalam aktifitas melaut. Hasil yang diperoleh menunjukkan bahwa aktifitas komunikasi masyarakat suku Bajo Sampela terdiri dari tiga bagian yakni komunikasi antara orang tua dan anak, komunikasi antar tetangga dan komunikasi antar anak. Aktifitas komunikasi terjadi baik di dalam ruang, di atas jembatan maupun ketika melaut.

Kata Kunci: aktifitas, melaut, orang tua, anak.
\end{abstract}


Jurnal IImu Komunikasi UHO : Jurnal Penelitian Kajian IImu Komunikasi dan Informasi.

Volume 6, No. 4, Oktober 2021, hlm 548-569

\title{
THE ETHNOGRAPHIC STUDY OF COMMUNICATION: FISHING ACTIVITIES AS A SOURCE OF LIFE FOR THE BAJO SAMPLEA TRIBE
}

\begin{abstract}
This research focuses on communication activities in fishing activities that are carried out by the Bajo Sampela tribal community; the communication activities involving language and culture in a series of fishing activities for the Bajo Sampela community. The researcher will describe the activities of the Bajo community and the verbal and nonverbal symbols used. This study aims to explain communication activities in the Bajo Sampela community regarding language, nonverbal symbols used in fishing culture. By using the ethnographic method of communication, the researcher focused on the ways of communication carried out by the Bajo Sampela people in their fishing activities. The results obtained indicated that the communication activities of the Bajo Sampela community consisted of three parts, namely communication between parents and children, communication between neighbors and communication between children. Communication activities occured both indoors, on bridges and while at sea.
\end{abstract}

Keywords: activity, fishing, parents, children. 
Jurnal IImu Komunikasi UHO : Jurnal Penelitian Kajian Ilmu Komunikasi dan Informasi. Volume 6, No. 4, Oktober 2021, hlm 548-569

\section{PENDAHULUAN}

Suku bajo dikenal sebagai pelaut tangguh yang tersebar dikepulauan Indonesia. Wakatobi salah satunya menjadi tempat suku bajo melangsungkan kehidupannya. Daerah Wakatobi yang dikelilingi oleh laut menjadikan peluang besar bagi suku bajo untuk menetap tinggal dan memanfaatkan kekayaan alam sebagai sumber kehidupannya. Diantaranya Suku Bajo Mantigola, Sampel, Loha yang mendiami wilayah Wakatobi.

Salah satu suku bajo yang unik adalah suku bajo Sampela. Lokasinya tepat diantara pulau Kaledupa dan pulau Hoga. Posisi tempat tinggalnya berada di tengah laut yang dibuat rumah panggung, dinding terbuat dari kombinasi kayu dan ayaman bambu dan daun rumbia digunakan sebagai atap. Namun, beberapa dari rumah suku bajo sampela ada juga yang menggunaan atap seng yang dapat dijumpai beberapa rumah. Kendaraan utama masyarakat suku bajo sampela adalah perahu. Perahu ini digunakan sebagai alat/kendaraan utama untuk melaut.

Dalam setiap tatanan masyarakat memikili sistem komunikasi sendiri yang membentuk suatu budaya dan Bahasa menjadi inti dari komunikasi sekaligus menjadi pembuka realitas bagi manusia. Dengan komunikasi, manusia dapat membentuk masyarakat dan kebudayaannya. Melalui komunikasi pula orang tua dapat mengajarkan berbagai kebiasaan kepada anak-anaknya. Sebab, komunikasi selalu hadir dalam lingkungan hidup kita. Tanpa terkecuali dalam lingkup hidup masyarakat suku bajo sampela.

Aktivitas melaut menjadi kebutuhan utama masyarakat suku bajo sampela. Masyarakat suku bajo Sampela memiliki kebiasaan unik yakni ketika melaut memperhatikan kondisi cuaca dan juga mendidik anak laki-laki untuk ikut melakukan aktifitas melaut. Dengan harapan anak menjadi pelaut Tangguh. Hal tersebut diajarkan turun temurun oleh orang tua kepada anak (terutama anak lakilaki). Sehingga menjadi kebiasaan yang rutin dilakukan hingga saat ini. Kepercayaan yang masih ada hingga saat ini yakni aAdanya roh halus sebagai penjaga laut, menyiapakan sesajen ektika melaut yang dianggap sebagai persembahan untuk roh penjaga laut menjadi suatu hal yang biasa dan dilakukan secara kontinyu oleh masyarakat suku bajo Sampela. Bahkan menjadi sebuah 
Jurnal IImu Komunikasi UHO : Jurnal Penelitian Kajian Ilmu Komunikasi dan Informasi.

Volume 6, No. 4, Oktober 2021, hlm 548-569

budaya baru. Budaya tersebut tentunya berkaitan dengan kepercayaan atau ideologi masyarakat pada suku Bajo Sampela.

Masyarakat suku Bajo Sampela sehari-hari bekerja sebagai nelayan dan untuk menghidupi keluarganya dari hasil melaut. Bahkan anak laki-laki ketika berusia 5 tahun diikutsertakan dalam aktifitas melaut. Hal ini dilakukan sebagai upaya orang tua dalam mentransfer pengetahuan melaut kepada anak. Sementara anak perempuan mengikuti ibunya untuk mendapatkan ari bersih, kayu yang dipakai memasak. Situasi seperti ini menjadi kebisaaan/budaya bagi masyarakat suku bajo Sampela.

Orang bajo sejak lahir sudah dikenal dengan kehidupan di atas permukaan air. Dalam pandangan masyarakat Bajo Sampela, meninggalkan cara hidup di laut sama halnya dengan meninggalkan adat istiadat hidup mereka. Bagi masyarakat Bajo, laut merupakan tempat satu-satunya untuk menetap dan tinggal. Sebagai komunitas yang tidak terpisahkan dari laut, masyarakat Suku Bajo Sampela menolak untuk menetap hidup di daratan. Sebab, tinggal di laut telah menjadi ritus bagi suku Bajo Sampela secara turun temurun.

Masyarakat Suku Bajo Sampela mempelajari tata cara menikmati hidup dengan mengais rezeki dari hasil melaut. Dari kegiatan melaut mampu menopang kebutuhan ekonominya. Kebiasaan yang kita jumpai bahwa setiap selesai melaut hasil yang diperoleh ditukar dengan barang (kebutuhan makan sehari-hari misalnya beras, sayuran dan lain-lain). Hal ini berarti masih terdapat sistem barter dalam jual beli pasa masyarakat suku Bajo Sampela. Sebagian hasil melaui dijual ke nelayan lain untuk menghasilkan uang.

Penelitian sebelumnya yang mengkaji suku Bajo sudah banyak dilakukan. Diantaranya membahas terkait kearifan lokasi suku bajo. Penelitian yang dilakukan oleh Fadliyah (2020) menujukkan bahwa kearofan lokasi meliputi nilainilai yang berlaku dalam masyakakat. Nilai-nilai diyakini kebenanrnya dan menjadi dasar dalam berperilaku sehari-hari. Sehingga kearifan lokasi merupakan entitas yang sangat menentukan harkat dan martabat manusia dalam sebuah komunitas (Fadhliyah H Dai, 2020). Penelitian lain juga dilakukan oleh Hadi (2020) yang menujukkan bahwa keterampilan social anak suka bajo Sampela di 
Jurnal IImu Komunikasi UHO : Jurnal Penelitian Kajian IImu Komunikasi dan Informasi.

Volume 6, No. 4, Oktober 2021, hlm 548-569

daerha Sulawesi Tenggara menjadi warisan budaha leluhur yang terwujud dalam kehiduapn sehari-hari misalnya Nganjama Sibbea (bekerja sama), Guru Sibbea (Bekerja Bersama), Kukuri Sibbea (Bermain Bersama), Si Jagaang (Saling melindungi), Situloh/Sibantoh (tolong menolong)

Selain itu, penelitian lain berfokus pada Keterampilan Sosial Anak Suku Bajo di Sulawesi Tenggara yang menujukkan bahwa keterampilan sosial anak suku Bajo sebagai warisan budaya leluhur terwujud dalam kehidupan sehari berupa Nganjama Sibbea (Bekerjasama), Guru Sibbea (Belajar bersama), Kukuri Sibbea (Bermain bersama), Si Jagaang (Saling melindungi), Situloh/Sibantoh (Tolong menolong), Ringan tangan membantu Soliditas, terimplementasi dalam pengabdian dan kepatuhan pada keluarga dan masyarakat (Hadi Machmud, 2020).

Dengan demikian, penelitian ini akan mendeskripsikan aktifitas melaut yang dilakukan masyarakat suku bajo Sampela. Kajian Etnografi Komunikasi digunakan untuk menjelaskan kegiatan komunikasi yang melibatkan bahasa dan budaya. Selain itu, penelitian ini mengungkap simbol verbal dan nonverbal yang dipakai dalam kegiatan melaut masyakat suku Bajo Sampela.

Menurut Agus M. Hardjana dalam (Sunarto, 2011) mengatakan, komunikasi antarpribadi melibatkan interaksi tatap muka antardua atau beberapa orang, pengirim dapat menyampaikan pesan secara langsung serta penerima dapat memberikan umpan balik secara langsung pula. Hal ini sejalan dengan pendapat (deddy), mengatakan bahwa komunikasi antarpribadi adalah komunikasi antara dua orang yang dilakukan secara tatap muka, yang memungkinkan setiap peserta didalamnya menangkap reaksi orang lain secara langsung, baik secara verbal maupun nonverbal.

Sementara, menurut Devito dalam (Sunarto, 2011) menyatakan komunikasi antarpribadi adalah proses pertukaran oleh satu orang dan penerima pesan kepada orang lain atau sekelompok kecil orang, untuk memberikan umpan balik segera. Berdasarkan definisi tersebut dapat dipahami bahwa komunikasi antarpribadi merupakan proses penyampaian pesan dan penerimaan pesan antara pengirim dan penerima baik secara langsung maupun tidak langsung. Komunikasi dikatakan secara langsung (primer) apabila pihak-pihak yang terlibat komunikasi dapat 
Jurnal IImu Komunikasi UHO : Jurnal Penelitian Kajian IImu Komunikasi dan Informasi.

Volume 6, No. 4, Oktober 2021, hlm 548-569

saling berbagi pesan. Sedangkan komunikasi tidak langsung (sekunder) dirincikan oleh adanya penggunaan media tertentu (Sunarto, 2011).

Terdapat beberapa ciri komunikasi yang menggunakan saluran komunikasi antarpribadi (Liliweri, 2007) yakni: (1) Arus pesan yang cenderung dua arah, (2) Konteks komunikasinya dua arah, (3) Tingkat umpan balik yang terjadi tinggi, (4) Kemampuan mengatasi tingkat selektivitas yang tinggi, (5) Kecepatan jangkauan terhadap audiens yang besar relative lambat dan (6) Efek yang mungkin terjadi adalah perubahan sikap.

Budaya sebagai „upaya deskriptif yang penting", „cara memandang pelbagai hal dan relasiee inilaih tepatnya yang telah merintangi perkembangan minat teoritis khusus pada bahasa dan praktik penandaan dalam Culural Studies yang akan memberi perhatian pada cara makna dikonstruksi dan dikomunikasikan (Struart Hall, 2011). Budaya secara inheren adalah bermakna dan makna berakar dalam pengalaman sosial praktis. Pada dasarnya, hal yang dibutuhkan hal ini adalah teori bahasa yang ekspersif, sementara makna linguistik dapat dirujuk pada realitas yang ,dideskripsikan makna-makna tersebut, makna itu tetap berakar dalam tindakan persepsi dan kreativitas yang pada dasarnya bersifat subjektif. Dalam pandangan ini, tuturan linguistik dapat dibaca kembali, atau „diinterpretasikan“, dalam kaitannya dengan „struktur perasaan ${ }^{e e}$ yang mendasari tuturan tersebut, sebagaimana dalam argumen Hoggart (Struart Hall, 2011).

"Kita harus mencoba melihat dibalik kebiasaan apa yang disimbolkan oleh kebiasaan itu, mencoba menyelami pernyataan apa yang sebetulnya dimaksudkan oleh pernyataan itu (yang mungkin berlawanan dengan pernyataan itu sendiri), mencoba mendeteksi tekanan emosi yang berbedabeda dibalik ungkapan idiom dan ketaatan Budayaistik".

Makna tanda individual terletak pada perbedaannya dengan semua tanda lainnya dalam rangkaian tanda. Teori bahasa Saussure secara implisit mengacu teori makna dan kesadaran secara rasionalis, sebab teori Saussure mengacu pada gagasan tentang tanda sebagai ide representasi yang mendahului tuturan aktual manapun serta kosekuensinya tidak berwaktu dan bebas konteks (Struart Hall, 2011).

Bahasa ada sebelum subjek individual yang berbicara, dan dengan diperolehnya bahasalah yakni, dengan mengambil posisi subjek yang berbicara 
Jurnal IImu Komunikasi UHO : Jurnal Penelitian Kajian Ilmu Komunikasi dan Informasi.

Volume 6, No. 4, Oktober 2021, hlm 548-569

dalam bahasa - individu manusia memperoleh subjektivitas yang sadar dan bergender. Sehingga kaitan antara bahasa sebagai pesan dengan objek yang diteliti adalah untuk membantu peneliti memahami masyarakat suku bajo Sampela dari penggunaan simbol-simbol bahasa yang dipakai misalnya penghalusan bahasa. Selain itu, peneliti ingin melihat peran penting bahasa dalam penyampaian pesan terhadap anak-anak di suku Bajo Sampela. Sebab, bahasa merupakan hal paling fundamental dalam suatu budaya. Bahasa akan memegang peranan penting dalam aktifitas budaya melaut oleh orang tua ke anak di suku Bajo Sampela. Bahasa menjadi kunci transfer pesan.

Kajian ini berusaha untuk menjelaskan mengenai aktivitas melaut mayarakat suku Bajo Sampela. Dell Hymes awalnya menyebut Entografi Komunikasi sebagai etnografi berbicara. Dengan menggunakan dua pendeakatan yakni pendekata linguistik dan etnografi. Kaitan antara Bahasa, budaya dan masyarakat menjadi fokus perhatian antropologis tradisional (Littlejohn, 2009).

Studi Etnografi komunikasi fokus pada satu kelompok yang unik, dalam hal ini peneliti mempelajari budaya sebuah kelompok melalui proses interaksi yang dilakukan. Melalui interkasi dalam kelompok tersebut, kita dapat melihat ekspresi dan perubahan sikap serta perilaku dari orang-orang yang terlibat dalam percakapan tersebut. Ketika individu dalam kelompok melakukan interkasi, biasanya perilakunya sama dengan individu lainnya dalam kelompok tersebut (Craig \& Cook, 2007).

Etnografi komunikasi mengkaji berbagai perilaku komunikasi yang muncul dari integrasi tiga keterampilan yang dimiliki setiap individu. Keterampilan tersebetu meliputi keterampilan linguistik, keterampilan interkasi dan keterampilan budaya. Ketiga keterampilan tersebut berupaya menggambarkan ruang lingkup etnografi komunikasi yang disebut sebagai kompetensi komunikasi (Kuswarno, 2008) .

Etnografi komunikasi menjadi sebuah pendekatan untuk menjelaskan masyarakat dan budaya dan rekonstruksi dari sebuah kelompok etnis tertentu. Untuk menjelaskan hal tersebut "Bahasa: diguanakan secara terstruktur oleh pola budaya, Bahasa bertindak sebagai alat komunikasi. Bahasa juga mentransmisikan budaya social melalui generasi. Peran perilaku pidato, salah satu aspek bahasa, selalu signifikan dalam penelitian antropologi budaya (Chinmay \& Ray, 2011). 
Jurnal IImu Komunikasi UHO : Jurnal Penelitian Kajian IImu Komunikasi dan Informasi. Volume 6, No. 4, Oktober 2021, hlm 548-569

Hymes dalam (Muriel, 2003) kembali menegaskan bahwa bahasa tidak dapat dipisahkan dari bagaimana dan mengapa digunakan, dan penggunaan bahasa sebagai syarat untuk mendapat pengakuan dan pemahaman. Dalam penggunaan bahasa terdapat kode-kode tertentu dan proses kognitif dalam mendengar bahasa. Dalam etnografi komunikasi bahasa mengambil posisi pertama sebagai bentuk budaya dalam lingkungan sosial.

Dengan demikian, etnografi komunikasi digunakan untuk menjelaskan aktifitas komunikasi dalam masyarakat suku Bajo Sampela yang melibatkan bahasa, simbol nonverbal dipakai dalam budaya melaut. Aktifitas komunikasi merupakan aktivitas yang khas dan berulang kali dilakukan yang melibatkan tindak-tindak komunikasi orang tua dan anak dalam aktivitas budaya melaut.

Penelitian ini bertujuan untuk untuk menggambarkan aktifitas komunikasi dalam masyarakat suku Bajo Sampela yang melibatkan bahasa, simbol nonverbal yang dipakai dalam budaya melaut. Aktifitas komunikasi adalah aktivitas yang khas dan berulang kali yang melibatkan tindak-tindak komunikasi oleh orang tua dan anak dalam aktivitas budaya melaut.

\section{METODE PENELITIAN}

Penelitian ini menggunakan pendekatan kualitatif, penekanannya pada kedalaman (kualitas) budak pada kuantitas (banyaknya) data (Kriyantono, 2006) . Melalui penelitian ini berupaya memahami fenomena tentang apa yang dialami oleh masyarakat suku bajo sampela, misalnya perilaku, komunikasi dalam keseharian terkait budaya melaut. Penelitian kualitatif dijelaskan sebagai suatu proses penelitian ilmiah untuk memahami berbagai masalah manusia dalam konteks sosial dengan menciptakan gambaran menyeluruh dan kompleks yang disajikan, menjelaskan situasi/kondisi secara rinci, serta dilakukan dalam setting alami tanpa adanya intervensi dari peneliti (Herdiansyah, 2010). Penelitian ini mengusung tradisi etnografi komunikasi merupakan penerapan dari metode etnografi pada cara-cara berinteraksi atau berkomunikasi dalam setiap peristiwa komunikasi dalam sebuah aktivitas melaut masyarakat suku bajo sampela. 
Jurnal IImu Komunikasi UHO : Jurnal Penelitian Kajian IImu Komunikasi dan Informasi. Volume 6, No. 4, Oktober 2021, hlm 548-569

Menurut (Kuswarno, 2008) bahwa etnografi merupakan ranah antropologi, linguistik dan komunikasi, sehingga etnografi komunikasi merupakan salah satu pendekatan yang interpretif. Sedangkan menurut Seville-Troike dalam (Kuswarno, 2008) menjelaskan bahwa fokus kajian etnografi komunikasi adalah masyarakat tutur atau (speech community), yang didalamnya mencakup: (a) cara bagaimana komunikasi dipola dan diorganisasikan sebagai sebuah sistem dari sistem peristiwa komunikasi, (b) cara-cara bagaimana komunikasi itu hidup dalam interaksi dengan komponen sistem kebudayaan yang lain. Berdasarkan uraian tersebut maka peneliti akan berupaya untuk memahami proses pembelajaran budaya melaut pada suku Bajo Sampela dalam menopang eksistensi budaya laut.

Adapun teknik pengumpulan data meliput observasi secara lansung, wawancara untuk mengkroscek hasil observasi dan jga dokumentasi. Observasi digunakan untuk mengamati secara langsung perilaku dan kegiatan sehari-hari masyarakat suku Bajo Sampela terkait objek penelitian (aktifita/kegiatan melaut, komunikasi yang dilakukan dan relasi sosial dalam lingkup komunitas suku Bajo Sampela). Ditambah studi dokumen meliputi catatan- catatan tentang suku bajo sampela (jumlah penduduk, kartu keluarga), data-data penelitian sebelumnya, data letak geografis suku bajo Sampela yang diperoleh dari desa Sama Bahari serta beberapa dokumen yang terkait dengan penelitian ini seperti penelitian terdahulu.

\section{HASIL DAN PEMBAHASAN}

Desa Sama Bahari merupakan kampung bajo Sampela yang bermukim di atas laut. Profesi nelayan yang menjadi pilihan satu-satunya suku Bajo Sampela telah lama digeluti dan dilakukan oleh masyarakat dari ge nerasi sebelumnya hingga saat ini. Melaut merupakan suatu kegiatan rutin yang dilakukan oleh masyarakat suku bajo Sampela. Hasil observasi peneliti di desa Sama Bahari menunjukkan bahwa laut sebagai tempat masyarakat suku Bajo Sampela untuk menopang kebutuhan ekonominya. Bahkan, dalam sebuah keluarga jika memiliki anak laki-laki, maka anak tersebutlah yang mengikuti bapak untuk menangkap ikan.

Berbicara tentang suku bajo sampela tidak telepas dari budaya melaut. Ini merujuk pada penggunaan terminologi atau istilah yang berkaitan dengan aktifitas melaut. Tedapat empat termonologi budaya melaut di suku bajo Sampela, yakni: 
Jurnal IImu Komunikasi UHO : Jurnal Penelitian Kajian IImu Komunikasi dan Informasi.

Volume 6, No. 4, Oktober 2021, hlm 548-569

Pertama, Palilibu artinya mencari ikan disekitar kampung bajo Sampela kemudian hasil tangkapan ikan dibawa kembali ke darat dan dijual. Bila hasil melaut berlimpah, maka ditukar dengan sayuran dan bahan pokok lainnya. Sistem melaut palilibu berlangsung hingga 1 hari dan tidak jauh dari wilayah perkampungan Sampela. Dominan masyarakat suku bajo Sampela melakoni budaya melaut dengan sistem Palilibu. Kedua, Pongka merupakan sistem melaut yang dilakukan pada saat musim teduh. Kegiatan melaut dengan sistem pongka dilakukan secara berkelompok berkisar 4-6 orang selama 7-10 hari. Jadi masyarakat malaut keluar ke karang dan tinggal di karang serta mencari karang yang strategis sehingga bisa menghasilkan banyak ikan. Jika lokasi karang dekat dengan pulau, maka masyarakat akan buat pondok (rumah gubuk) untuk tempat tinggal sementara selama melaut di daerah tersebut. Setelah itu tangkapan di awetkan dengan es batu atau dikeringkan sampai tiba kembali di desa sama bahari. Hasil tangkapan berupa ikan, teripang dan udang baru. Pola ini biasa dilakukan pada bulan Oktober sampai Desember.

Ketiga, Sakai artinya masyarakat suku Bajo mencari ikan dilokasi yang sangat jauh sampai melintasi batas wilayah daerah maupun negara. Bisanya target utamanya di wilayah Australia, Timur Leste sampai Madagaskar. Mereka mencari ikan, teripang, lola di lokasi strategis. Sehingga mereka tidak kenal wilayah perbatasan. Ini adalah budaya yang dilakukan orang tua zaman dahulu masih tetap dilakukan hingga saat ini. Terakhir Lamaa, artinya merantau untuk mencari ikan. biasanya nelayan yang merantau menjadi karyawan di daerah lain dan bekerja sama dengan pihak yang melakukan penangkapan ikan dalam skala besar. Sistem melaut ini juga dilakukan di suku Bajo Sampela. Tetapi jumlahnya sedikit. Hal ini juga disebabkan oleh masyarakat suku Bajo Sampela tidak berpendidikan sehingga kurang memahami mengenai batas-batas wilayah perairan Indonesia.

Aktivitas komunikasi yang peneliti maksud adalah suatu kegiatan yang berlangsung dalam setiap proses komunikasi pada masyarakat suku bajo Sampela terutama berkaitan dengan kegiatan melaut yang melibatkan bapak dan anak. Kegiatan budaya melaut merupakan suatu aktivitas yang didalamnya terdapat interaksi dan pertukaran pesan diantara individu. Hal ini memberikan makna bahwa terjadinya komunikasi antarpribadi yang merupakan penciptaan makna dalam budaya melaut. 
Jurnal IImu Komunikasi UHO : Jurnal Penelitian Kajian IImu Komunikasi dan Informasi.

Volume 6, No. 4, Oktober 2021, hlm 548-569

Dalam aktifitasnya sehar-hari masyarakat suku bajo sampela terlibat dalam komunikasi kelompok baik diantara keluarga inti maupun tetangga rumah. Aktifitas komunikasi keluarga inti melibatkan komunikasi antara orang tua dan anak. Dengan menggunakan analisis Hymes yang mengelompokkan komunikasi ke dalam delapan kelompok yang masing-masing dilabeli dari kata "SPEAKING" yang berfungsi sebagai sarana pengingat yang terdiri dari Setting (Situasi), Participant (Peserta yang terlibat), End (tujuan/akhir percakapan), Act Sequence (urutan tindakan), Key (Kunci), Instrumentalist (kode verbal/Nonverbal), Norms Of Interaction (norma interkasi) dan Genre (tipe peristiwa) (Kuswarno, 2008).

\section{Komunikasi Orang Tua dan Anak}

Pada umumnya manusia berkomunikasi menggunakan bahasa verbal dan diikuti penggunaan bahasa nonverbal. Mengkaji atau membahas tentang komunikasi verbal berarti membahas tentang bahasa. Bahasa penting bagi manusia untuk mengungkapkan segala bentuk keinginannya, paling tidak ia dapat menyatakan dirinya sendiri dan orang lain disekitarnya.

Komuniaksi yang berlangsung dalam aktifitas melaut melibatkan orang tua dan anak. Pertukaran pesan baik verbal maupun nonverbal yang terjadi pada masyarakat suku Bajo Sampela. Dalam aktifitas melaut terjalin komunikasi antar pribadi (orang tua dan anak(. Menurut (Mulyana, 2008) komunikasi antarpribadi adalah komunikasi antara dua orang secara tatap muka, yang memungkinkan setiap pesertanya menangkap reaksi orang lain secara langsung, baik secara verbal maupun nonverbal.

Berikut rangkaian aktifitas komunikasi antara orang tua dan anak dalam kaitannya dengan aktifitas melaut, sebagai berikut: 
Jurnal IImu Komunikasi UHO : Jurnal Penelitian Kajian Ilmu Komunikasi dan Informasi.

Volume 6, No. 4, Oktober 2021, hlm 548-569

Tabel 1.1 Aktifitas Komunikasi Orang Tua dan Anak

\begin{tabular}{|c|c|c|c|c|c|c|c|c|}
\hline $\begin{array}{c}\text { AKTIFI } \\
\text { TAS }\end{array}$ & SITUATION & PARTICIPANT & $E N D$ & ART SEQUENCE & $K E Y$ & $\begin{array}{l}\text { INSTRU } \\
\text { MENT }\end{array}$ & NORMS & GENRE \\
\hline $\begin{array}{l}\text { 1. Ritual } \\
\text { Memandi } \\
\text { kan Bayi } \\
\text { Berusia } 3 \\
\text { Bulan }\end{array}$ & $\begin{array}{l}\text { Di sekitar } \\
\text { Pemukiman suku } \\
\text { bajo Sampela }\end{array}$ & $\begin{array}{l}\text { Bapak, Ibu, Anak } \\
\text { dan Tokoh } \\
\text { Masyarakat }\end{array}$ & $\begin{array}{l}\text { Agar jiwa anak laki- laki menyatu } \\
\text { dengan laut Berharap ketika anak } \\
\text { dewasa bisa menjadi pelaut seperti } \\
\text { orang } \\
\text { tuanya }\end{array}$ & $\begin{array}{l}\text { Ibu duduk bersila di atas perahu bersama } \\
\text { anak, kemudian anak diberikan ke bapak } \\
\text { agar anak bisa dilewati di bawah perahu, } \\
\text { lalu ibu menyambut kembali anak tersebut } \\
\text { di atas perahu. }\end{array}$ & $\begin{array}{l}\text { Pernyataan, } \\
\text { Nasehat }\end{array}$ & Bahasa bajo & $\begin{array}{l}\text { Ibu duduk bersila di } \\
\text { atas leppa } \\
\text { Bapak berada di } \\
\text { samping leppa } \\
\text { (perahu) }\end{array}$ & $\begin{array}{l}\text { Memberikan } \\
\text { nasehat kepada } \\
\text { kedua orang tua. } \\
\text { Orang tua } \\
\text { mendengarkan } \\
\text { nasehat dengan } \\
\text { seksama } \\
\text { Berdoa }\end{array}$ \\
\hline $\begin{array}{l}\text { 2. Anak } \\
\text { diajar } \\
\text { berenang } \\
\text { pada usia } \\
\text { 3-5 tahun }\end{array}$ & $\begin{array}{l}\text { Di sekitar } \\
\text { pemukiman suku } \\
\text { bajo Sampela }\end{array}$ & Bapak dan Anak & $\begin{array}{l}\text { Memperkena lkan kepada anak } \\
\text { tentang } \\
\text { kebiasaan suku laut } \\
\text { Melatih anak agar bisa berenang }\end{array}$ & $\begin{array}{l}\text { Bapak memberikan anak "jerigeng air } \\
\text { kosong" untuk } \\
\text { dipakai anak sehingga anak bisa } \\
\text { mengapung di air } \\
\text { Anak mengambil jeringeng kemudian } \\
\text { jeringeng ditangkupkan di bawah dada } \\
\text { sehingga bisa mengapung di laut } \\
\begin{array}{l}\text { Bapak mengawasi anak dari atas Jembatan } \\
\text { sambil menunjuk kearah anak }\end{array}\end{array}$ & Perintah & $\begin{array}{l}\text { Bahasa } \\
\text { bajo }\end{array}$ & $\begin{array}{l}\text { Bapak duduk di atas } \\
\text { jembatan sambil } \\
\text { mengamati } \\
\text { anak yang sedang } \\
\text { belajar berenang }\end{array}$ & $\begin{array}{l}\text { Bapak } \\
\text { menuntun anak } \\
\text { cara berenang }\end{array}$ \\
\hline $\begin{array}{l}\text { 3. Anak } \\
\text { belajar } \\
\text { membuat } \\
\text { jaring }\end{array}$ & $\begin{array}{l}\text { Di atas perahu } \\
\text { (tengah laut) }\end{array}$ & Bapak dan Anak & $\begin{array}{l}\text { Agar anak tahu membuat jaring } \\
\text { ikan } \\
\text { Mengajarkan anak agar mahir dalam } \\
\text { menurunkan jaring di karang (laut) }\end{array}$ & $\begin{array}{l}\text { Bapak menyebutkan bahan untuk } \\
\text { membuat jaring meliputi tasi, tali, bola } \\
\text { hitam sebagai pelampung, potongan } \\
\text { sendal dan timah sambil menunjukkan } \\
\text { cara menjahit jaring Anak mendengarkan } \\
\text { dan mempraktekan sesuai arahan bapak } \\
\\
\text { Bapak mematikan mesin bodi } \\
\text { kemudian mendayung dari sebelah } \\
\text { kana agar bodi dapat berjalan sesuai } \\
\text { maju sebelah kiri sambil menyuruh } \\
\text { anak menurunkan jaring secara } \\
\text { perlahan-lahan } \\
\text { Anak menurunkan jaring sesuai arahan } \\
\text { bapak }\end{array}$ & $\begin{array}{l}\text { Pernyataa, } \\
\text { perintah }\end{array}$ & $\begin{array}{l}\text { Bahasa } \\
\text { bajo } \\
\\
\\
\text { Bahasa } \\
\text { bajo }\end{array}$ & $\begin{array}{l}\text { Bapak duduk } \\
\text { sambil } \\
\text { menunjukkan cara } \\
\text { membuat jaring } \\
\text { Anak melihat, } \\
\text { menyimak dan } \\
\text { mencoba mengikuti } \\
\text { apa yang dilakukan } \\
\text { bapak } \\
\text { Bapak duduk di } \\
\text { ujung belakang } \\
\text { atau depan perahu } \\
\text { sambil mendayung } \\
\text { Anak berada di } \\
\text { tengah perahu lalu } \\
\text { menutunkan } \\
\text { jaring sepanjang } 1000 \\
\text { meter }\end{array}$ & $\begin{array}{l}\text { Percakapan } \\
\text { antara bapak } \\
\text { dan anak } \\
\text { dalam suasana } \\
\text { santai }\end{array}$ \\
\hline
\end{tabular}

ISSN: 2527-9173. Website: http://ojs.uho.ac.id/index.php/KOMUNIKASI/index 
Jurnal IImu Komunikasi UHO : Jurnal Penelitian Kajian Ilmu Komunikasi dan Informasi.

Volume 6, No. 4, Oktober 2021, hlm 548-569

\begin{tabular}{|c|c|c|c|c|c|c|c|c|}
\hline AKTIFITAS & SITUATION & PARTICIPANT & $E N D$ & ART SEQUENCE & $K E Y$ & $\begin{array}{l}\text { INSTRUM } \\
\text { ENT }\end{array}$ & NORMS & GENRE \\
\hline $\begin{array}{l}\text { 4. Anak belajar } \\
\text { membuat alat } \\
\text { panah } \\
\text { ikan }\end{array}$ & $\begin{array}{l}\text { Di karang } \\
\text { (tengah } \\
\text { laut }\end{array}$ & $\begin{array}{l}\text { Bapak dan } \\
\text { Anak }\end{array}$ & $\begin{array}{l}\text { Agar anak dapat } \\
\text { membuat alat panah } \\
\text { ikan } \\
\\
\text { Supaya anak pandai } \\
\text { dalam memanah } \\
\text { ikan }\end{array}$ & $\begin{array}{l}\text { Bapak menyiapkan besi dan kayu } \\
\text { sebagai bahan dasar dalam membuat } \\
\text { panah. Kemudian, bapak memasang } \\
\text { besi dengan mengaitkannya pada panah } \\
\text { dan diikat dengan menggunakan tali } \\
\text { (karet ban). Anak memperhatikan apa } \\
\text { yang dilakukan oleh bapak dan } \\
\text { mengikuti secara perlahan-lahan. Panah } \\
\text { ikan seperti senjata } \\
\text { Bapak turun ke laut dan mempraktekan } \\
\text { cara memanah ikan yakni menyelam, } \\
\text { berburu ikan kemudian ikannya di } \\
\text { panah dengan menekan salah satu besi } \\
\text { yang dibuat secara khusus untuk } \\
\text { memangsa ikan } \\
\text { Anak mengikuti apa yang } \\
\text { dilakukan oleh bapak }\end{array}$ & $\begin{array}{l}\text { Pernyataa, } \\
\text { perintah } \\
\text { nasehat }\end{array}$ & Bahasa bajo & $\begin{array}{l}\text { Bapak dan anak duduk di teras rumah sambil } \\
\text { mengerjakan /membuat panah Ikan } \\
\text { Anak melihat secara saksama dalam setiap } \\
\text { proses pembuatan panah } \\
\text { Bapak dan anak secara bersamaan terjun ke } \\
\text { laut dan menyelam }\end{array}$ & $\begin{array}{l}\text { Bapak bercerita } \\
\text { kepada anak } \\
\text { terkait cara } \\
\text { membuat alat } \\
\text { panah ikan }\end{array}$ \\
\hline $\begin{array}{l}\text { 5. Anak belajar } \\
\text { membuat alat } \\
\text { menyulu ikan } \\
\text { (tombak) } \\
\\
\text { Anak belajar } \\
\text { mengkap ikan } \\
\text { dengan memakai } \\
\text { tombak (menyulu) }\end{array}$ & $\begin{array}{l}\text { Di karang } \\
\text { (tengah } \\
\text { laut) }\end{array}$ & $\begin{array}{l}\text { Bapak dan } \\
\text { Anak }\end{array}$ & $\begin{array}{l}\text { Supaya anak tahu } \\
\text { dan bisa membuat } \\
\text { alat menyulu ikan } \\
\text { (tombak) } \\
\\
\begin{array}{l}\text { Agar anak mahir } \\
\text { dalam menangkap } \\
\text { ikan }\end{array}\end{array}$ & $\begin{array}{l}\text { Bapak mengambil bambu sebagai alat } \\
\text { pegang tombak, kemudian } \\
\text { mengikatkanya dengan besi yang } \\
\text { bercabang tiga atau lima } \\
\text { Anak melihat dan mengikuti cara } \\
\text { besi yang disambung dengan } \\
\text { bambu } \\
\text { Bapak mengajarkan kepada anak } \\
\text { menyulu ikan bisa dilakukan dari } \\
\text { atas perahu dan juga bisa dengan } \\
\text { cara menyelam } \\
\text { Anak awalnya belajar dari atas leppa } \\
\text { atau solo-solo lalu kemudian belajar } \\
\text { dengan menyelam sesuai arahan } \\
\text { bapak }\end{array}$ & $\begin{array}{l}\text { Pernyataa, } \\
\text { perintah }\end{array}$ & Bahasa bajo & $\begin{array}{l}\text { Sebelum ke karang biasanya bapak } \\
\text { membaca doa untuk keselamatan selama } \\
\text { proses belajar melaut } \\
\text { yang dilalui oleh anaknya }\end{array}$ & $\begin{array}{l}\text { Khusyu, doa (doa } \\
\text { yang ditujukkan } \\
\text { kepada } \\
\text { "Bojanggo" Dewa } \\
\text { Laut agar selalu } \\
\text { melindungi dan tidak } \\
\text { mengganggu } \\
\text { selama berada di } \\
\text { karang }\end{array}$ \\
\hline $\begin{array}{l}\text { 6. Anak belajar } \\
\text { membuat alat } \\
\text { pancing tradisional } \\
\text { Anak belajar } \\
\text { memancing } \\
\text { menggunakan alat } \\
\text { tradisional }\end{array}$ & $\begin{array}{l}\text { Di atas } \\
\text { jembatan } \\
\text { dan di } \\
\text { atas } \\
\text { perahu } \\
\text { Di karang } \\
\text { (tengah } \\
\text { laut) }\end{array}$ & $\begin{array}{l}\text { Bapak dan } \\
\text { Anak }\end{array}$ & $\begin{array}{l}\text { Anak bisa mandiri } \\
\text { dalam menyiapkan } \\
\text { dan membuat alat } \\
\text { pancing } \\
\text { tradisional } \\
\text { Anak mahir dalam } \\
\text { memancing ikan }\end{array}$ & $\begin{array}{l}\text { Bapak mengambil tasi, kemudian } \\
\text { anak mencari umpan berupa cacing, } \\
\text { ikan kecil dan sebagainya. } \\
\text { Bapak mengajarkan anak cara } \\
\text { memasang umpan ikan di mata } \\
\text { pancing untuk bisa mendapat ikan } \\
\text { besar (ikan putih, ekor kuning dan } \\
\text { sebagainya }\end{array}$ & $\begin{array}{l}\text { Pernyataa } \\
\text { n perintah } \\
\text { Pernyataa, } \\
\text { perintah }\end{array}$ & $\begin{array}{l}\text { Bahasa bajo } \\
\text { Bahasa bajo }\end{array}$ & $\begin{array}{l}\text { Bapak mengajarkan cara mengaitkan } \\
\text { umpan di mata pancing tradisional } \\
\text { Bapak mengajarkan anak dalam memancing } \\
\text { membutuhkan kesabaran untuk } \\
\text { mendapat ikan }\end{array}$ & $\begin{array}{l}\text { Obrolan santai, tetap } \\
\text { sopan } \\
\text { Obrolan santai, } \\
\text { dikarenakan } \\
\text { memancing ikan } \\
\text { butuh waktu dan } \\
\text { kesabaran }\end{array}$ \\
\hline
\end{tabular}

ISSN: 2527-9173. Website: http://ojs.uho.ac.id/index.php/KOMUNIKASI/index 
Jurnal IImu Komunikasi UHO : Jurnal Penelitian Kajian Ilmu Komunikasi dan Informasi.

Volume 6, No. 4, Oktober 2021, hlm 548-569

\begin{tabular}{|c|c|c|c|c|c|c|c|c|}
\hline AKTIFITAS & SITUATION & PARTICIPANT & $E N D$ & ART SEQUENCE & $K E Y$ & $\begin{array}{l}\text { INSTRUM } \\
\text { ENT }\end{array}$ & NORMS & GENRE \\
\hline $\begin{array}{l}\text { 4. Anak belajar } \\
\text { membuat alat } \\
\text { panah } \\
\text { ikan }\end{array}$ & $\begin{array}{l}\text { Di karang } \\
\text { (tengah } \\
\text { laut }\end{array}$ & $\begin{array}{l}\text { Bapak dan } \\
\text { Anak }\end{array}$ & $\begin{array}{l}\text { Agar anak dapat } \\
\text { membuat alat panah } \\
\text { ikan } \\
\\
\text { Supaya anak pandai } \\
\text { dalam memanah } \\
\text { ikan }\end{array}$ & $\begin{array}{l}\text { Bapak menyiapkan besi dan kayu } \\
\text { sebagai bahan dasar dalam membuat } \\
\text { panah. Kemudian, bapak memasang } \\
\text { besi dengan mengaitkannya pada panah } \\
\text { dan diikat dengan menggunakan tali } \\
\text { (karet ban). Anak memperhatikan apa } \\
\text { yang dilakukan oleh bapak dan } \\
\text { mengikuti secara perlahan-lahan. Panah } \\
\text { ikan seperti senjata } \\
\text { Bapak turun ke laut dan mempraktekan } \\
\text { cara memanah ikan yakni menyelam, } \\
\text { berburu ikan kemudian ikannya di } \\
\text { panah dengan menekan salah satu besi } \\
\text { yang dibuat secara khusus untuk } \\
\text { memangsa ikan } \\
\text { Anak mengikuti apa yang } \\
\text { dilakukan oleh bapak }\end{array}$ & $\begin{array}{l}\text { Pernyataa, } \\
\text { perintah } \\
\text { nasehat }\end{array}$ & Bahasa bajo & $\begin{array}{l}\text { Bapak dan anak duduk di teras rumah sambil } \\
\text { mengerjakan /membuat panah Ikan } \\
\text { Anak melihat secara saksama dalam setiap } \\
\text { proses pembuatan panah } \\
\text { Bapak dan anak secara bersamaan terjun ke } \\
\text { laut dan menyelam }\end{array}$ & $\begin{array}{l}\text { Bapak bercerita } \\
\text { kepada anak } \\
\text { terkait cara } \\
\text { membuat alat } \\
\text { panah ikan }\end{array}$ \\
\hline $\begin{array}{l}\text { Anak belajar } \\
\text { mengkap ikan } \\
\text { dengan memakai } \\
\text { tombak (menyulu) }\end{array}$ & $\begin{array}{l}\text { Di karang } \\
\text { (tengah } \\
\text { laut) }\end{array}$ & $\begin{array}{l}\text { Bapak dan } \\
\text { Anak }\end{array}$ & $\begin{array}{l}\text { Supaya anak tahu } \\
\text { dan bisa membuat } \\
\text { alat menyulu ikan } \\
\text { (tombak) }\end{array}$ & $\begin{array}{l}\text { Bapak mengambil bambu sebagai alat } \\
\text { pegang tombak, kemudian } \\
\text { mengikatkanya dengan besi yang } \\
\text { bercabang tiga atau lima } \\
\text { Anak melihat dan mengikuti cara } \\
\text { besi yang disambung dengan } \\
\text { bambu } \\
\text { Bapak mengajarkan kepada anak } \\
\text { menyulu ikan bisa dilakukan dari } \\
\text { atas perahu dan juga bisa dengan } \\
\text { cara menyelam } \\
\text { Anak awalnya belajar dari atas leppa } \\
\text { atau solo-solo lalu kemudian belajar } \\
\text { dengan menyelam sesuai arahan } \\
\text { bapak }\end{array}$ & $\begin{array}{l}\text { Pernyataa, } \\
\text { perintah }\end{array}$ & Bahasa bajo & $\begin{array}{l}\text { Sebelum ke karang biasanya bapak } \\
\text { membaca doa untuk keselamatan selama } \\
\text { proses belajar melaut } \\
\text { yang dilalui oleh anaknya }\end{array}$ & $\begin{array}{l}\text { Khusyu, doa (doa } \\
\text { yang ditujukkan } \\
\text { kepada } \\
\text { "Bojanggo" Dewa } \\
\text { Laut agar selalu } \\
\text { melindungi dan tidak } \\
\text { mengganggu } \\
\text { selama berada di } \\
\text { karang }\end{array}$ \\
\hline $\begin{array}{l}\text { 6. Anak belajar } \\
\text { membuat alat } \\
\text { pancing tradisional } \\
\text { Anak belajar } \\
\text { memancing } \\
\text { menggunakan alat } \\
\text { tradisional }\end{array}$ & $\begin{array}{l}\text { Di atas } \\
\text { jembatan } \\
\text { dan di } \\
\text { atas } \\
\text { perahu } \\
\text { Di karang } \\
\text { (tengah } \\
\text { laut) }\end{array}$ & $\begin{array}{l}\text { Bapak dan } \\
\text { Anak }\end{array}$ & $\begin{array}{l}\text { Anak bisa mandiri } \\
\text { dalam menyiapkan } \\
\text { dan membuat alat } \\
\text { pancing } \\
\text { tradisional } \\
\begin{array}{l}\text { Anak mahir dalam } \\
\text { memancing ikan }\end{array}\end{array}$ & $\begin{array}{l}\text { Bapak mengambil tasi, kemudian } \\
\text { anak mencari umpan berupa cacing, } \\
\text { ikan kecil dan sebagainya. } \\
\text { Bapak mengajarkan anak cara } \\
\text { memasang umpan ikan di mata } \\
\text { pancing untuk bisa mendapat ikan } \\
\text { besar (ikan putih, ekor kuning dan } \\
\text { sebagainya }\end{array}$ & $\begin{array}{l}\text { Pernyataa } \\
\text { n perintah } \\
\text { Pernyataa, } \\
\text { perintah }\end{array}$ & $\begin{array}{l}\text { Bahasa bajo } \\
\text { Bahasa bajo }\end{array}$ & $\begin{array}{l}\text { Bapak mengajarkan cara mengaitkan } \\
\text { umpan di mata pancing tradisional } \\
\text { Bapak mengajarkan anak dalam memancing } \\
\text { membutuhkan kesabaran untuk } \\
\text { mendapat ikan }\end{array}$ & $\begin{array}{l}\text { Obrolan santai, tetap } \\
\text { sopan } \\
\text { Obrolan santai, } \\
\text { dikarenakan } \\
\text { memancing ikan } \\
\text { butuh waktu dan } \\
\text { kesabaran }\end{array}$ \\
\hline
\end{tabular}

ISSN: 2527-9173. Website: http://ojs.uho.ac.id/index.php/KOMUNIKASI/index 
Jurnal IImu Komunikasi UHO : Jurnal Penelitian Kajian Ilmu Komunikasi dan Informasi.

Volume 6, No. 4, Oktober 2021, hlm 548-569

Berdasarkan tabel di atas, ditemukan bahwa Komunikasi orang tua dan anak dalam aktifitas melaut dilakukan secara tatap muka dengan intensitas komunikasi yang tinggi. Hal ini terjadi hamper disemua kesempatan misalnya ketika orang tua dan anak berkumpul di depan rumah atau di atas jembatan. Bahkan ketika menyiapkan alat dan bahan sebelum melaut. Komunikasi yang dilakukan oleh orang tua terhadap anak termasuk dalam komunikasi antar pribadi.

Aktifitas budaya melaut yang melibatkan anak suku bajo Sampela sebagai upaya orang tua untuk mewariskan budaya melaut. Ini dilakukan melalui komunikasi sehari-hari dan juga kebiasaan membawa anak laki-laki ketika melaut. Dalam hal ini komunikasi antarpirbadi menjadi komponen utama dalam keberhasilan penyampaian pesan dari orang tua kepada anak. Devito dalam (Sunarto, 2011) menjelaskan komunikasi antarpribadi adalah penyampaian pesan oleh satu orang dan penerima pesan oleh orang lain atau sekelompok kecil orang, dengan dampaknya dan peluang untuk memberikan umpan balik segera. Dalam hal ini, aktifitas budaya melaut, orang tua terutama Ayah (Bapak) yang dominan dalam mentrasfer pesan (pengetahuan) kepada anak terkait budaya melaut. Proses komunikasi ini terjadi secara tatap mula yang mana anak mendengarkan apa yang disampaikan oleh bapak serta anak memberikan respon/umpan balik terhadap bapak.

\section{Aktifitas Komunikasi Antar Tetangga dalam Budaya Melaut}

Komunikasi kelompok dianggap efektif dimana masing-masing individu mengambil peran aktif dalam setiap perisitiwa komunikasi. Setiap individu berkak mengambul peran di dalam peristiwa komunikasi. Komunikasi yang terjalin diantara inidvidu yang terlibat mampu menumbuhkan kesepahaman Bersama. Diantraanya komunikasi dengan para tetangga yang melibatkan beberapa orang membentuk suatu kelompok.

Komunikasi yang berlangsung setiap harinya pada masyarakat suku Bajo Sampela terjadi dalam sebuah kelompok. Komunikasi kelompok selalu ada karena menggambarkan manusia sebagai makhluk yang ingin bekerja sama dan saling ketergantungan. Sebab hidup berkelompok juga merupakan wadah manusia untuk mengkomunikasikan tentang kelangsungan hidupnya. Berikut potret aktifitas komunikasi antar tetangga dalam budaya melaut. 
Jurnal IImu Komunikasi UHO : Jurnal Penelitian Kajian IImu Komunikasi dan Informasi.

Volume 6, No. 4, Oktober 2021, hlm 548-569

Tabel 1.2 Komunikasi Antar Tetangga dalam Budaya Melaut

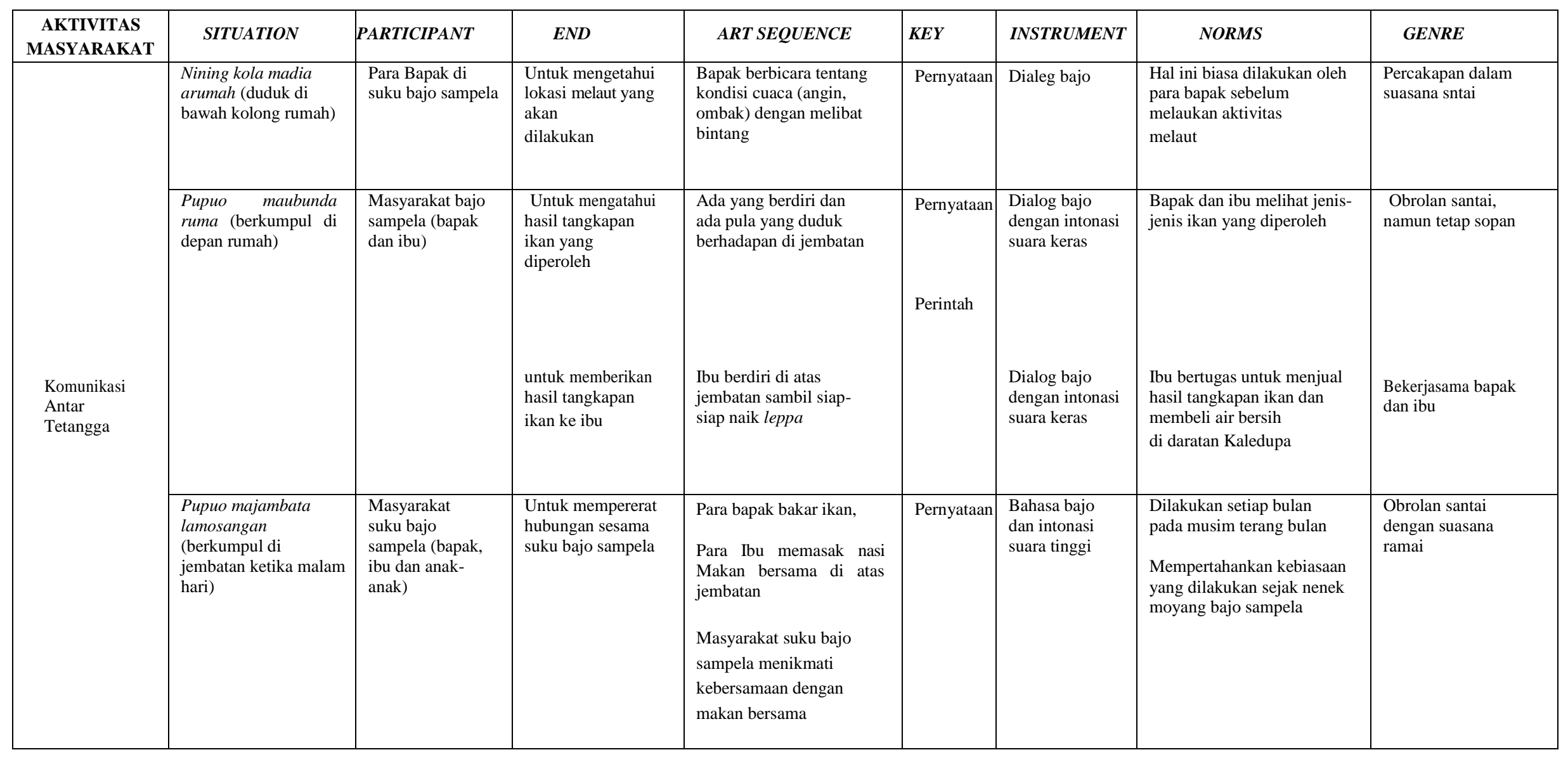

ISSN: 2527-9173. Website: http://ojs.uho.ac.id/index.php/KOMUNIKASI/index 
Jurnal IImu Komunikasi UHO : Jurnal Penelitian Kajian Ilmu Komunikasi dan Informasi.

Volume 6, No. 4, Oktober 2021, hlm 548-569

Berbagai hal diperbincangkan antar tetangga, akan tetapi hal yang paling dominan di perbincangkan adalah tentang cara mengajarkan anak menangkap ikan untuk mempertahankan eksistensi budaya melaut. Para orang tua tidak pernah sama sekali membahas tentang pendidikan formal untuk anak-anaknya. Bagi mereka, seorang anak yang penting bisa memperoleh uang maka anak tersebut dikatakan sukses. Memperoleh uang tentunya melalui kegiatan melaut. Sehingga, orang tua melakukan transfer pengetahuan budaya melaut kepada anak.

Komunikasi yang berlangsung antar tetangga terkait budaya melaut merupakan hal yang sangat penting terutama cara memasang jaring yang baik, cara memanah ikan, menombak ikan sampai teknik memancing. Selain itu, yang diperbincangkan adalah mengenai lokasi mencari ikan yang hasilnya tangkapannya banyak.

Berdasarkan tabel di atas, terdapat pola suku bajo sampela dalam berkomunikasi dengan tetangga dalam aktifitas melaut, sebagai berikut: (1) Budaya kumpul dengan tetangga kerap terlihat setiap harinya, dominan terjadi pada sore dan malam hari di suku bajo Sampela. (2) Jika dikalangan bapak yang menjadi topik perbincangan yakni perkembangan anak-anak suku Bajo Sampela dalam keahlian melaut, hasil tangkapan hari itu dan lokasi tujuan menangkap ikan esok hari. Jika dikalangan ibu-ibu yang menjadi bahan perbincangan adalah kebutuhan dapur seharihari. (3) Antara ibu dan bapak yang menjadi topik pembicaraan adalah kegiatan ibu yang akan menjual hasil tangkapan ikan ke daratan Kaledupa.

Komunikasi antar tetangga dan antar anak dapat dikategorikan sebagai komunikasi kelompok. Budaya kumpul dengan tetangga telah ada sejak lama di suku Bajo Sampela. Bahkan sebelum pergi melaut para tetangga saling memanggil dan membangunkan jika berangkat melaut di waktu subuh. Hal ini menunjukkan adanya kohesivitas yang tinggi diantara masyarakat suku Bajo Sampela. Komunikasi kelompok selalu terjadi dalam suatu budaya tertentu tanpa terkecuali di suku Bajo Sampela. Menurut (Liliweri, Makna Budaya Dalam Komunikasi Antarbudaya, 2007) Komunikasi kelompok merupakan komunikasi di antara sejumlah orang (kalau kelompok kecil berjumlah 4-20 orang, dan kelompok besar 20-50 orang) di dalam sebuah kelompok.

\section{Komunikasi Antar Anak}

Komunikasi yang terjalin pada masyarakat suku bajo Sampela tidak hanya terjadi pada orang tua dan anak, antar tetangga tetapi juga antar anak. Hasil 
Jurnal IImu Komunikasi UHO : Jurnal Penelitian Kajian IImu Komunikasi dan Informasi.

Volume 6, No. 4, Oktober 2021, hlm 548-569

pengamatan peneliti menunjukkan bahwa anak-anak di suku Bajo Sampela selalu berkumpul ketika pulang dari melaut. Adapun lokasi berkumpulnya anak tergantung pada usia anak tersebut. Anak-anak yang berusia dibawah 10 tahun dominan berkumpul di balai desa sambil bermain tali (anak perempuan) dan bermain kartu untuk anak laki- laki. Dalam situasi lain, terdapat anak laki-laki yang bermain air di samping rumah atau ada yang belajar mendayung bersama teman yang lain. Suasana ramai kerap terlihat jika jam sekolah (pagi hari) dan menjelang sore hari. Anak perempuan yang bermain tali secara berulang bernyanyi dalam bahasa Bajo.

Berikut komunikasi antar anak dalam aktifitas budaya melaut: 
Jurnal IImu Komunikasi UHO : Jurnal Penelitian Kajian Ilmu Komunikasi dan Informasi.

Volume 6, No. 4, Oktober 2021, hlm 548-569

\section{Tabel 1.3 Komunikasi Antar Anak dalam Budaya Melaut}

\begin{tabular}{|c|c|c|c|c|c|c|c|c|}
\hline $\begin{array}{l}\text { AKTIVIT } \\
\text { AS ANAK }\end{array}$ & SITUATION & PARTICIPANT & $E N D$ & ART SEQUENCE & KEY & INSTRUMENT & NORMS & GENRE \\
\hline \multirow[t]{3}{*}{$\begin{array}{l}\text { Komunikasi } \\
\text { Antar Anak }\end{array}$} & $\begin{array}{l}\text { Pupuo kola madia arumah } \\
\text { (Berkumpul di bawah } \\
\text { kolong rumah) } \\
\text { Di karang } \\
\text { (laut) }\end{array}$ & $\begin{array}{l}\text { Anak Laki-laki } \\
\text { Anak Laki-laki }\end{array}$ & $\begin{array}{l}\text { Untuk mengisi } \\
\text { waktu luang } \\
\text { sambil bermain } \\
\text { bilyar } \\
\text { Menjalin hubungan } \\
\text { kekerabatan } \\
\text { melalui memancing } \\
\text { ikan bersama }\end{array}$ & $\begin{array}{l}\text { Berdiri sambil bermain bilyar } \\
\text { dan membahas tentang hasil } \\
\text { tangkapan ikan yang } \\
\text { diperoleh } \\
\text { Kemudian, bercerita tentang } \\
\text { rencana berangkat melaut } \\
\text { besok Anak laki-laki } \\
\text { menggunakan leppa atau solo- } \\
\text { solo kemudian pergi di sekitar } \\
\text { pulau hoga dan memancing } \\
\text { ikan putih }\end{array}$ & $\begin{array}{l}\text { Pernyataan } \\
\text { Pernyataan }\end{array}$ & $\begin{array}{l}\text { Nonformal, lisan } \\
\text { menggunakan } \\
\text { bahasa bajo }\end{array}$ & $\begin{array}{l}\text { Kegiatan yang sejak } \\
\text { dulu dilakukan oleh } \\
\text { anak laki-laki karena } \\
\text { kondisi pemukiman } \\
\text { suku bajo sampela } \\
\text { jauh dari darat }\end{array}$ & Obrolan ringan \\
\hline & $\begin{array}{l}\text { Di atas leppa } \\
\text { (perahu) }\end{array}$ & $\begin{array}{l}\text { Anak } \\
\text { Perempuan }\end{array}$ & $\begin{array}{l}\text { Untuk membeli air } \\
\text { bersih di daratan } \\
\text { Kaledupa }\end{array}$ & $\begin{array}{l}\text { Naik leppa (perahu), membawa } \\
\text { banyak jeringeng kosong ke } \\
\text { daratan Kaledupa. } \\
\text { Membeli air bersih yang } \\
\text { kemudian di bawah ke bajo } \\
\text { sampela. } \\
\text { Jika angin bertiup } \\
\text { kencang menggunakan } \\
\text { layar tradisional, akan } \\
\text { tetapi jika tidak, memakai } \\
\text { dayung. }\end{array}$ & Perintah & $\begin{array}{l}\text { Nonformal, lisan } \\
\text { menggunakan } \\
\text { bahasa bajo }\end{array}$ & $\begin{array}{l}\text { Kebiasaan yang sela;u } \\
\text { dilakukan pada pagi } \\
\text { dan sore hari }\end{array}$ & $\begin{array}{l}\text { Dalam suasan santai } \\
\text { karena sebagai kegiatan } \\
\text { rutin }\end{array}$ \\
\hline & $\begin{array}{l}\text { Nubba ketika meting (air } \\
\text { laut turun) }\end{array}$ & $\begin{array}{l}\text { Anak Laki- } \\
\text { laki dan anak } \\
\text { perempuan }\end{array}$ & $\begin{array}{l}\text { Untuk memperolah } \\
\text { bulu babi, teripang, } \\
\text { udang pasir, keong } \\
\text { kecil \& sebagainya }\end{array}$ & $\begin{array}{l}\text { Anak perempuan dan laki-laki } \\
\text { secara berkelompok turun ke } \\
\text { laut dengan kondisi air laut } \\
\text { hingga betis. Mereka } \\
\text { memasukan tangannya ke } \\
\text { dalam pasir kemudian meraba } \\
\text { sampai menemukan udang } \\
\text { pasir, teripang dan } \\
\text { sebagainya }\end{array}$ & Pernyataan & $\begin{array}{l}\text { Nonformal, lisan } \\
\text { menggunakan } \\
\text { bahasa bajo }\end{array}$ & $\begin{array}{l}\text { Kebiasaan yang selalu } \\
\text { dilakukan anak-anak } \\
\text { suku bajo sampela jika } \\
\text { metting tiba. Sebab } \\
\text { mereka tidak memiliki } \\
\text { daratan untuk berjalan }\end{array}$ & $\begin{array}{l}\text { Obrolan ringan satu } \\
\text { sama lain }\end{array}$ \\
\hline
\end{tabular}

ISSN: 2527-9173. Website: http://ojs.uho.ac.id/index.php/KOMUNIKASI/index 
Jurnal Ilmu Komunikasi UHO : Jurnal Penelitian Kajian Ilmu Komunikasi dan Informasi.

Volume 6, No. 4, Oktober 2021, hlm 548-569

Komunikasi antar anak juga terjadi antar anak laki-laki dan perempuan. Komunikasi yang terjalin ketika anak-anak akan melakukan kegiatan nubba. Nubba adalah salah satu kegiatan yang digemari anak- anak yang dapat dilakukan ketika air laut turun, maka anak-anak tersebut turun ke laut dan mencari berbagai macam hewan laut seperti bulu babi, teripang, udang pasir dan sebagainya. biasanya anak laki-laki dan perempuan tergabung dari satu kelompok yakni 3-5 orang.

Kegiatan budaya melaut merupakan suatu aktivitas yang didalamnya terdapat interaksi dan pertukaran pesan diantara inividu. Hal ini memberikan makna bahwa terjadinya komunikasi antarpribadi yang merupakan penciptaan makna dalam budaya melaut.

Menurut Agus M. Hardjana dalam (Sunarto, 2011) menjelaskan, komunikasi antarpribadi melibatkan interaksi tatap muka antardua atau beberapa orang, dimana pengirim dapat menyampaikan pesan secara langsung dan penerima pesan dapat menerima dan menanggapi secara langsung juga. Seperti halnya, komunikasi yang terjalin antara orang tua anak yang berlangsung setiap hari baik di depan rumah atau di jembatan ketika mempersiapkan kegiatan melaut.

Bahasa yang digunakan setiap berkomunikasi adalah bahasa bajo, baik dalam bentuk komunikasi dialog, percakapan (verbal) maupun nonverbal dengan ekspresi wajah serta menggerakkan tangan untuk menegaskan perkataan dengan tujuan untuk menyamakan persepsi di antara kedua belah pihak yang saling berkomunikasi. Hal ini sejalan dengan pernyataan (Mulyana, Ilmu Komunikasi: Suatu Pengantar, 2001 ) komunikasi dapat dikatakan efektif apabila komunikasi yang hasilnya sesuai dengan harapan komunikan (orang-orang yang terlibat dalam proses komunikasi) dan latar balakang yang sama juga mempengaruhi efektifan komunikasi. Dengan demikian, komunikasi tidak akan berlangsung secara komunikatif tanpa adanya bahasa sebagai simbol dan penciptaan makna pesan terkait kegiatan budaya melaut yang dipertukarkan, baik bahasa secara verbal maupun nonverbal. Bahasa verbal dan nonverbal yang digunakan saat berkomunikasi tentang kegiatan budaya melaut tersebut merupakan hal yang paling fundamental untuk saling melengkapi pada saat berinteraksi dalam suatu kelompok masyarakat.

\section{KESIMPULAN}

Aktifitas komunikasi dalam kegiatan melaut yang berlangsung pada masyarakat suku Bajo Sampela melibatkan orang tua, anak serta para tetangga 
Jurnal Ilmu Komunikasi UHO : Jurnal Penelitian Kajian IImu Komunikasi dan Informasi.

Volume 6, No. 4, Oktober 2021, hlm 548-569

sekitar. Komunikasi orang tua dan anak dalam budaya melaut dilakukan secara tatap muka yang tergambar dalam sejumlah aktifitas misalnya aktivitas komunikasi yang dilakukan oleh orang tua dan anak ketika mempersiapkan berbagai alat dan bahan dan selama kegiatan budaya melaut berlangsung. Aktivitas komunikasi berlangsung di depan rumah, di atas jembatan dan ketika berada di tengah laut (di atas perahu). Sehingga, pola komunikasi terkait kegiatan melaut yakni pola komunikasi keluarga inti yang melibatkan bapak, ibu dan anak. Bentuk komunikasi keluarga inti pada umumnya semua sama di suku bajo Sampela khususnya terkait kegiatan budaya melaut. 
Jurnal IImu Komunikasi UHO : Jurnal Penelitian Kajian Ilmu Komunikasi dan Informasi.

Volume 6, No. 4, Oktober 2021, hlm 548-569

\section{DAFTAR PUSTAKA}

Chinmay, \& Ray. (2011). A Study on Etnography of Communication: A discourse analysis with Hymes "speaking model". Journal of Education and Practice, ISSN 2222-1735, Vol 2, No 6.

Craig, M. A., \& Cook, I. (2007). Doing Etnographies. London: SAGE Publications.

Fadhliyah H Dai, R. M. (2020). Kearifan Lokal Masyarakat Suku Bajo Studi Etnografi Nilai-Nilai Pendidikan Agama dan Budi Pekerti pada Praktek Ritual Keagamaan di Desa Bajo Kecamatan Tilamuta. PEKERTI: Jurnal Pendidikan Islam dan Budi Pekerti, Volume 1. Nomor 1. Februari 2020.

Hadi Machmud, N. A. (2020). Keterampilan Sosial Anak Suku Bajo di Sulawesi Tenggara. Jurnal Obsesi : Jurnal Pendidikan Anak Usia Dini, ISSN: 2549-8959 .

Herdiansyah, H. (2010). Metode Penelitian untuk Ilmu-lmu Sosial. Jakarta: Salemba Humanika.

Kriyantono, R. (2006). Teknis Praktis Riset Komunikasi. Jakarta: PT. Kencana Perdana.

Kuswarno, E. (2008). Etnografi Komunikasi. Bandung: Widia Padjadjaran.

Liliweri, A. (2007). Makna Budaya dalam Komunikasi Antarbudaya. Yogyakarta: LKis Pelangi Aksara.

Liliweri, A. (2007). Makna Budaya Dalam Komunikasi Antarbudaya. Yogyakarta: PT. LKis Pelangi Aksara.

Liliweri, A. (2007). Makna Budaya Dalam Komunikasi Antarbudaya. Yogyakarta: LKis Pelangi Aksara.

Littlejohn, S. W. (2009). Teori Komunikasi Edisi 9. Jakarta: Salemba Humanika.

Mulyana, D. (2001). Ilmu Komunikasi: Suatu Pengantar. Bandung: PT. Remaja Rosdakarya.

Mulyana, D. (2008). Metodologi Penelitian Kualitatif, Paradigma Baru Ilmu Komunikasi dan Ilmu Sosial Lainnya. Bandung: PT. Remaja Rosdakarya.

Muriel, S. (2003). The Etnography of Communication, An Introduction Thrid Edition. German: Blackwell Publishing.

Struart Hall, D. H. (2011). Budaya, Media dan Bahasa. Yogyakarta: Jayasutra.

Sunarto, A. (2011). Komunikasi Interpersonal. Yogyakarta: Graha Ilmu. 